\title{
Desenvolvimento pós-embrionário do intestino médio de Dermatobia hominis (Linnaeus Jr.) (Diptera, Cuterebridae)
}

\author{
Edy de Lello ${ }^{1}$ \\ Ana Maria Vieira ${ }^{2,3}$
}

\begin{abstract}
Post-embryonic development of Dermatobia hominis (Linnaeus Jr.) (Diptera, Cuterebridae) midgut. Dermatobia hominis (Linnaeus, 1781) midgut is internally lined by an epithelium of polytenic cells, some low others prismatic with well developed brush border. Their apical portion are enlarged by secretory vesicles, forming button-like structures that are pinched off to the lumen, some accompained by the nucleus characterizing apocrine and holocrine secretions. This epithelium is gradually renewed by small, non polytenic regenerative cells, found scattered at its basal portion. At the end of the third instar the metamorphosis begins. The epithelial cells present signs of degeneration and at the first day of pupation the regenerative cells increase in number. By the $5^{\text {th }}$ day of pupation these regenerative cells, besides being increased in number, differentiate themselves into two layers: one similar to the dense conective tissue that sustainning the larval epithelium is pinched off to the midgut lumen forming the "yellow bodies"; the other, develops right under it as the imaginal epitelium. The disorganized muscles bundles of the midgut wall, are invaded by phagocytes. At the end of pupation the midgut has a low prismatic epithelium with brush-border. In the adult, the torax portion of the midgut has prismatic homogeneously basophilic epithelium while in the abdominal portion the epithelium is made of high prismatic cells full of small vacuoles. The larval midgut epithelium suffers programmed cell death non compatible with apoptose. During the metamorphosis the midgut lenght diminishes from $31 \mathrm{~mm}$ in the larva to $14 \mathrm{~mm}$ in the adult.

KEY WORDS. Diptera, Dermatobia hominis, midgut, metamorphosis, histology, post-embryonic development
\end{abstract}

Trabalhos sobre a morfologia interna do berne são encontrados, em LELLO et al. (1984, 1985, 1987); GREGÓRIO et al. 1981, 1990a,b, 1992).

VIEIRA \& LELLO (1996) desecreveram o desenvolvimento anatômico do tubo digestivo de $D$. hominis e observaram que de maneira geral ele é similar aos de outros dípteros muscóides, não apresentando entretanto, papo e cecos intestinais, em qualquer estágio do desenvolvimento e nem glândulas salivares na fase adulta. O tubo digestivo de $D$. hominis consta de três porções anatômicas distintas: o intestino anterior, o qual inclui como regiões diferenciadas, a faringe, o esôfago e o cárdia; o intestino médio e o intestino posterior.

Este trabalho tem como objetivo mostrar as modificações histológicas do intestino médio (IM) de $D$. hominis durante o período pós embrionário.

1) Departamento de Morfologia, Instituto de Biociências, Universidade Estadual Paulista. 18618-000 Botucatu, São Paulo, Brasil. E-mail: montenegro@laser.com.br

2) Departamento de Biologia, Universidade do Sagrado Coração. 17044-160 Bauru, Săo Paulo, Brasil. E-mail: labbio@usc.br

3) Bolsista- FAPESP processo $n^{\circ}$ 94/2589-9. 


\title{
MATERIAL E MÉTODOS
}

\author{
Neste trabalho, foi empregada a mesma metodologia descrita em VIEIRA \& \\ LELLO (2001).
}

\section{RESULTADOS}

A parede do intestino médio, em L2 e L3 possui externamente uma túnica própria bem desenvolvida onde penetram traquéias de vários calibres. Internamente a essa túnica existem feixes musculares sendo cerca de oito longitudinais externos ao longo de todo o comprimento do órgão e os circulares internos, provocando um pregueamento da parede. Revestindo internamente o tubo digestivo e acompanhando esse pregueamento existe um epitélio assentado sobre delicado tecido conjuntivo. Separando o epitélio do bolo alimentar, há a membrana peritrófica. No epitélio de revestimento foram identificados dois tipos celulares: as absortivas e as regenerativas. As primeiras, por apresentarem-se ora como prismáticas altas, ora baixas e com núcleos em diferentes alturas, dão muitas vezes, a impressão de constituirem um epitélio pseudoestratificado. As células altas não podem ser simplesmente denominadas colunares, pois suas superfícies apicais são frequentemente bastante alargadas em relação às superfícies basais. Células baixas podem aparecer entre as células altas ou em extensões isoladas ao longo do tubo. Entre esses dois tipos celulares existem, na porção basal do epitélio, células pequenas com núcleos não politênicos que aparecem isoladas, dispersas, raramente observadas em divisão. Tanto as células altas como as baixas apresentam notável bordadura estriada. As superfícies dilatadas das células epiteliais são de aspecto variado, podendo tomar a forma da porção alargada de uma pera ou de um cogumelo (Fig.1). Os núcleos, politênicos, ora são encontrados na porção mediana da célula, ora nessa porção apical dilatada. $\mathrm{O}$ citoplasma apresenta-se geralmente basófilo, nas porções basal e mediana sendo bastante acidófilo na porção apical. Vesículas de secreção de tamanhos variados e/ou porções apicais do citoplasma com ou sem núcleo podem ser observados no espaço endoperitrófico. É freqüente a formação de constrições da porção apical do citoplasma, tomando a forma de botões, prontos para "brotar" e cheios de vesículas com secreção acidófila (Fig. 2). A coloração pelo PAS revela grande quantidade de material PAS + nessas células, tendo sido parcial o bloqueio pela diastase (Fig. 3a,b). $\mathrm{Na}$ região basal do epitélio, observa-se núcleos com diferentes graus de politenia, e muito raramente, célula em divisão (Fig. 3a, detalhe).

Em L3 mais adiantada no desenvolvimento, as células digestivas podem apresentar grandes vacúolos no citoplasma. Em L3 "madura", isto é, caída espontaneamente do hospedeiro para pupar e em pré-pupa de um dia os aspectos apresentados pelo epitélio podem ser semelhantes, embora variáveis. Eles mantêm o pregueamento característico das larvas, podendo apresentar as células digestivas mais baixas, com discreta basofilia na porção basal do citoplasma, com esparsos vacúolos e núcleos com compactação irregular conferindo-lhes forma e tamanho variados. Outras vezes apresentam as células com núcleos alterados podendo mostrar os cromossomos rechaçados na periferia, os citoplasmas acidófilos e bastante vacuolizados, se desprendendo das demais em direção à luz. Em outras porções pode-se já observar as células regenerativas formando quase uma camada contínua sob o epitélio larval altamente vacuolizado. 

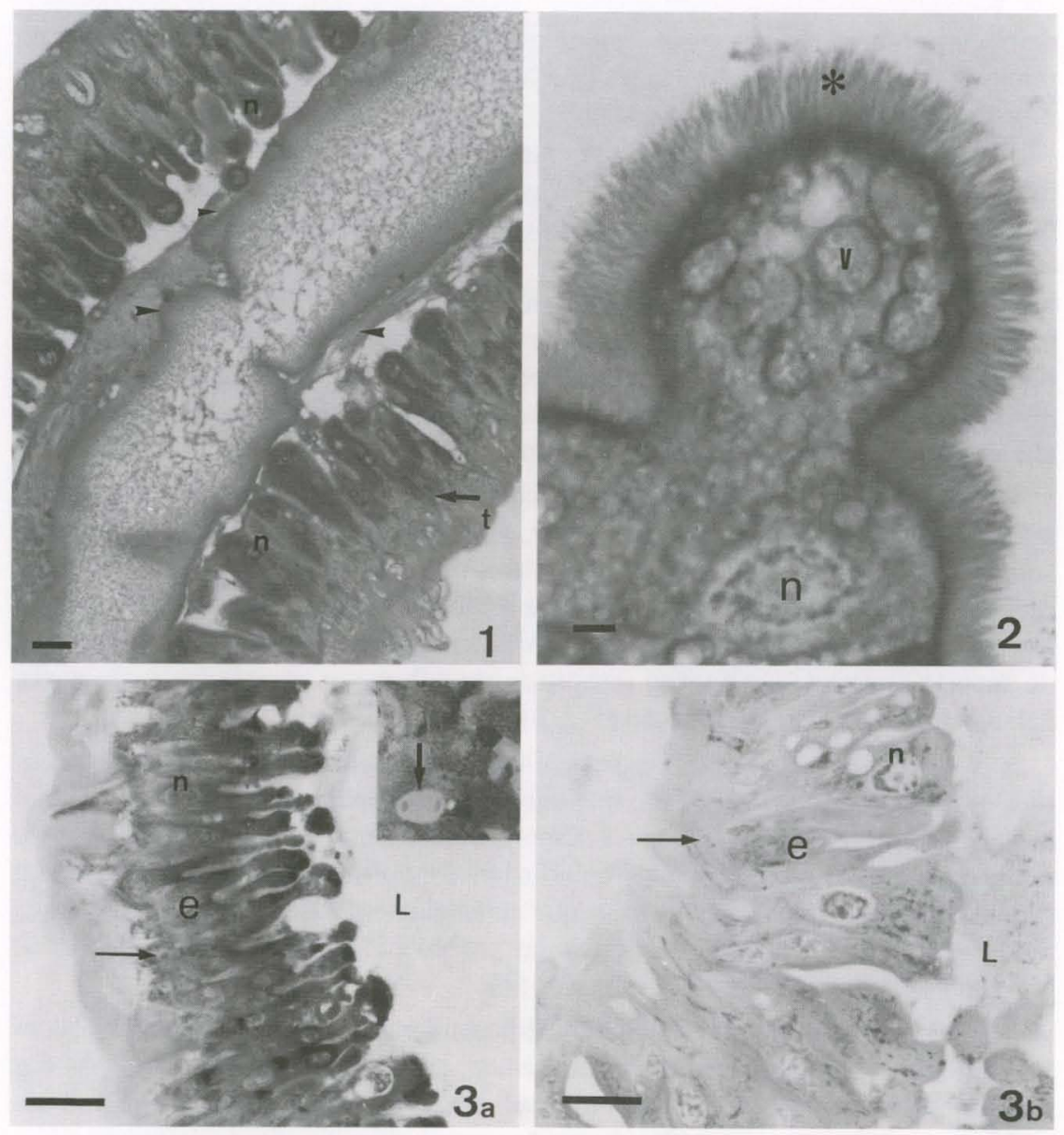

Figs 1-3. Dermatobia hominis, preparação HF. (1) Corte longitudinal do intestino médio (IM) de L2 (50 mg). Notar a membrana peritrófica (cabeça da seta) envelopando o alimento na luz do tubo digestivo e as dilataçōes apicais das células digestivas; ( $t$ ) Túnica própria, ( $n$ ) núcleo das células digestivas, (seta) núcleo da célula regenerativa, barra $=30 \mu \mathrm{m}$. (2) Detalhe de um "botão apical" de uma célula digestiva do IM em L3 $(110 \mathrm{mg})$, mostrando a bordadura estriada $\left(^{*}\right)$ bem desenvolvida e vesículas (v) com secreção acidófila; $(n)$ núcleo, barra= $10 \mu \mathrm{m}$. (3) Corte longitudinal do IM de L2 (50 mg); (a) reação ao PAS bastante intensa nas dilatações apicais. Detalhe: célula regenerativa em telófase (seta grossa); (b) bloqueio do PAS pela diastase em corte seqüencial; (e) epitélio, (L) luz (n) núcleo da célula digestiva, (seta fina) núcleo da célula regenerativa, barra $20 \mu \mathrm{m}$.

Em pré-pupas de dois dias, desaparece o pregueamento do epitélio, o que resta da camada de células digestivas se achata, no citoplasma surgem regiões acidófilas, os vacúolos desaparecem e os núcleos se condensam apresentando forma e tamanho variados. A bordadura estriada permanece. No escasso tecido conjuntivo, entre esse epitélio e a camada muscular interna, observa-se uma seqüência contínua 
de núcleos muito pequenos das células regenerativas. A camada muscular mostra início de fragmentação, a túnica própria torna-se proeminente, resultando em uma aspecto espessado dessa camada (Fig.4).

No quarto dia de pupação se intensificam os sinais de desintegração da musculatura; entre ela e o epitélio original, o aumento do número de células regenerativas forma uma camada irregular de células com núcleos pequenos, citoplasma difícil de ser individualizado apresentando alguns vacúolos. A túnica própria parece mais espessa e bastante dobrada. O epitélio larval, ainda presente, torna-se prismático e em vários pontos aparece desprendendo-se da nova camada imaginal, locais onde se observa uma secreção acidófila entre eles (Fig. 5). Essa nova camada celular apresenta consideráveis regiões do citoplasma PAS+ que quase chegam à negatividade após digestão com diastase.

No quinto dia o epitélio larval, com núcleos muito densos e irregulares, mantendo ainda as projeções para a luz, aparece "solto" na cavidade intestinal, suportado pela camada de células irregulares que tomam agora aspecto de tecido conjuntivo denso; esse tecido acompanha as dobras feitas por esse epitélio, sendo por isso mais espessa nessas regiões. O epitélio imaginal é visto abaixo desse tecido de suporte limitando a cavidade intestinal. Ele é formado por células prismáticas, baixas, de difícil individualização (Fig. 6).

As células do epitélio imaginal apresentam citoplasma com pequenos vacúolos e material PAS+, os quais se mantêm após a digestão pela diastase. $\mathrm{O}$ epitélio larval apresenta reação positiva ao PAS, porém mais fraca e de maneira difusa pelo citoplasma. O tecido que sustenta o epitélio larval que está sendo descartado também possui material PAS +. A parede muscular completamente desorganizada é invadida pelos fagócitos. O epitélio larval permanece em blocos soltos na cavidade intestinal; esta vai se enchendo de um líquido acidófilo.

A partir do nono dia o intestino médio vai tomando a forma de um fuso, com o progressivo alargamento da porção central, sendo mantidos os diâmetros das regiões anterior e posterior. Nestas últimas, as células de revestimento interno são mais altas, enquanto que aquelas da região central, dilatada, são mais baixas.

Ao redor do $15^{\circ}$ dia a primeira porção do epitélio intestinal parece ser pseudoestratificado para em seguida, em direção à porção posterior apresentar-se prismático baixo, com vacúolos citoplasmáticos.

A partir do $20^{\circ}$ dia, em algumas pupas, o epitélio do intestino médio é prismático, com bordadura estriada, núcleo central, vacúolos ao seu redor e próximos à porção apical; na porção basal o citoplasma mostra regiões PAS+ que se negativam após digestão pela diastase. Outras pupas apresentam epitélio prismático baixo, núcleos mais basalmente localizados, citoplasma basófilo com vacúolos na região basal; em todas, porém observa-se facilmente a bordadura estriada, bem desenvolvida na membrana apical.

Em adultos recém-emergidos, o epitélio da porção anterior do intestino médio, localizada no tórax, pode ser cúbico ou prismático, com núcleos pequenos, centrais ou basais e o citoplasma basófilo e homogêneo. Na transição para cavidade abdominal observa-se um discreto aumento do diâmetro do tubo. O epitélio sofre 

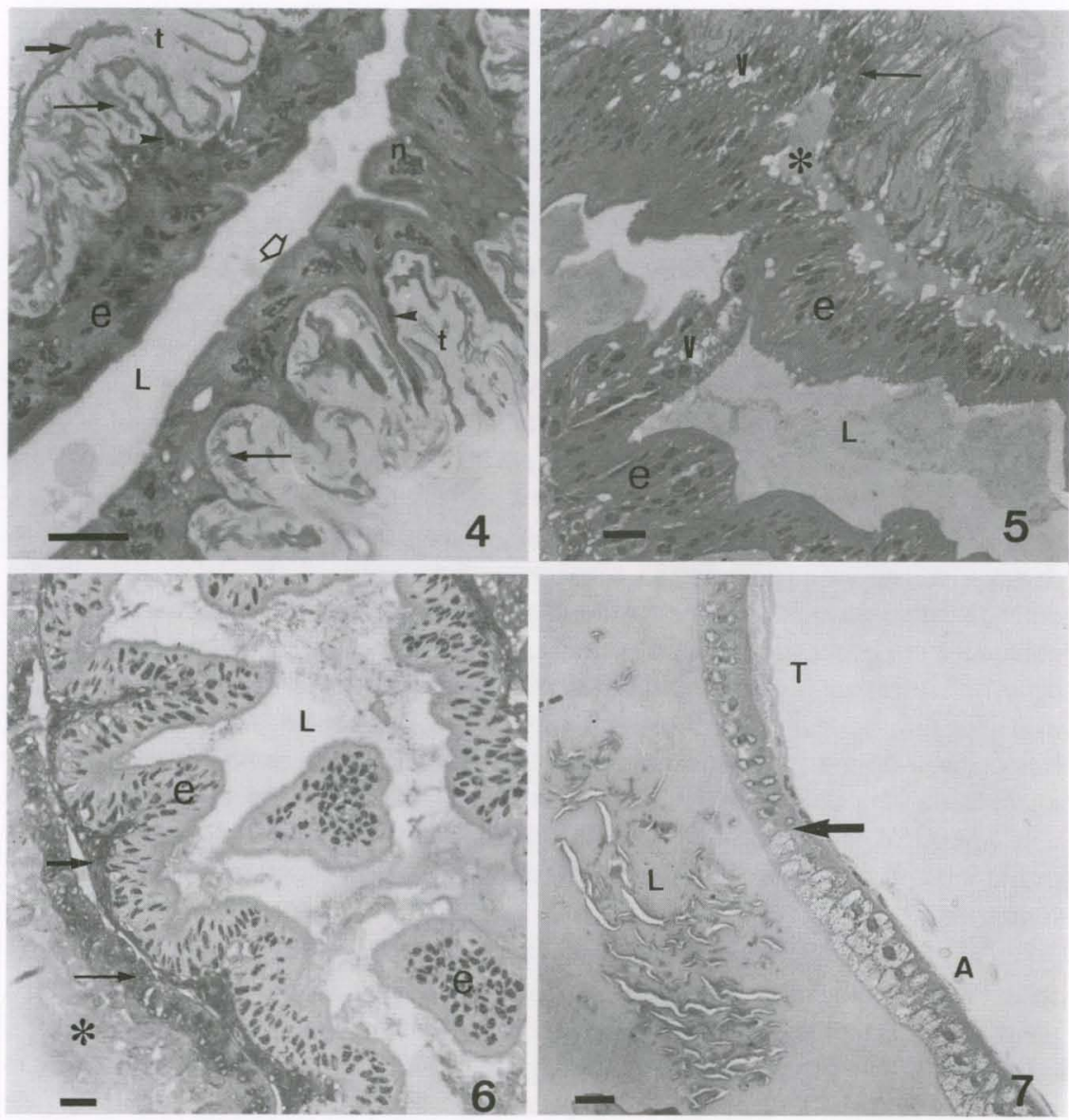

Figs 4-7. Dermatobia hominis, preparação HF. (4) Corte longitudinal no intestino médio (IM) de pré-pupa de dois dias. Notar o início de fragmentação nas camadas musculares longitudinal (seta grossa) e circular (seta fina); (cabeça da seta) núcleos de células regenerativas; (seta vazia) bordadura estriada; (e) epitélio; ( $L$ ) luz; ( $n$ ) núcleo; (t) túnica própria; barra=20 $\mu \mathrm{m}$. (5) Corte longitudinal de IM pupas no quarto dia de papação. Epitélio larval (e) se desprendendo em direção à luz; células regenerativas na região basal do epitélio (seta); secreção acidófila (*) entre os epitélios regenerativo e larval; (v) vacúolos; barra=50 $\mu \mathrm{m}$. (6) Corte longitudinal de IM de pupa no quinto dia de pupação. Parede muscular desorganizada (*). Epitélio larval (e) se desprendendo em direção à luz, tecido denso (seta grossa) sustentando o epitélio larval, (seta fina) epitélio imaginal; barra $=50 \mu \mathrm{m}$. (7) Corte longitudinal de IM de adulto recém-emergido; limite (seta) entre as regiōes torácica $(\mathrm{T})$ e abdominal $(\mathrm{A})$; barra $=50 \mu \mathrm{m}$.

marcante mudança, apresentando células prismáticas com núcleos centrais e citoplasma repleto de pequenos vacúolos claros (Fig. 7). Esse epitélio pode se projetar para a luz e é sustentado por duas delicadas camadas musculares sendo a interna circular e a externa longitudinal (Fig. 7). A reação do PAS mostra, nas células da 
região abdominal muito pouco material positivo ao redor dos vacúolos claros; já na porção torácica, as células apresentam maior quantidade de material PAS+. Em ambos os casos, a digestão prévia pela diastase não alterou a intensidade dessa reação.

\section{DISCUSSÃO E CONCLUSÕES}

As observações sob microscopia de luz limitam bastante as diferenciações mais finas do epitélio intestinal de insetos. Neste estudo foi possível identificar dois tipos celulares principais, revestindo internamente o intestino médio nas larvas de $D$. hominis: as epiteliais digestivas e as regenerativas. Estas últimas, muito pequenas, isoladas, localizadas junto à membrana basal, mantendo certa distância entre elas. As digestivas mostraram variações em seus aspectos durante os dois instares larvais. Em todos os ínstares observou-se a extrusão de porções globulosas apicais, sem ou com núcleo, para a luz de intestino, o que caracteriza os dois tipos clássicos de secreção: apócrina e holócrina, respectivamente. SNODGRASS (1935) discute que embora este último possa ser considerado um processo de secreção, existe quem o considere um processo de desintegração, após exaustão da secreção pela célula. É difícil afirmar que a célula epitelial sofreu exaustão, mas é fácil entender que, se está liberando parte de seu citoplasma com o núcleo, está fadada à morte e, a secreção holócrina, implica na morte da célula secretora. Embora tenha sido difícil, foi encontrada uma célula no epitélio intestinal da larva, em mitose, o que nos permite concluir que o epitélio do IM, durante o período larval é substituído parcialmente e de maneira progressiva, à medida em que as células digestivas morrem após secreção holócrina.

O epitélio larval de $D$. hominis é trocado inteiramente apenas na metamorfose. Verificou-se que esse prócesso é iniciado nas larvas "maduras", com a progressiva degeneração do epitélio larval e o aumento das células regenerativas que rapidamente forma uma camada irregular, ora muito compactada junto à porção basal das células larvais, ora se desprendendo das primeiras. No quinto dia de pupação, surge sob esse arranjo, com aspecto de tecido conjuntivo denso, uma outra camada de células, iniciando um arranjo em um epitélio simples. Nesse momento portanto, o epitélio pupal do intestino médio de $D$. hominis apresenta três camadas distintas: a velha, larval e as duas pupais. ANDRIÉs $(1970,1972)$ descrevendo a metamorfose de IM de Odonata da família Aeshnidae faz referência ao aparecimento dessas duas camadas pupais; chama a primeira de "tecido reticulado" e a outra de epitélio imaginal, sendo ambas resultantes da diferenciação das células regenerativas, que em seu objeto de estudo aparecem agrupadas em ninhos junto à membrana basal; afirma que as células situadas no ápice do ninho irão diferenciar no "tecido reticulado", que é transitório, vacuolizado e que, separará o antigo epitélio larval do novo imaginal; que o resultado do desenvolvimento das células situadas na base no ninho formará o epitélio da imago. Nos mesmos estudos descreve que o epitélio larval e o "tecido reticulado" são lançados no lúmen intestinal, onde sofrem histólise. DEPRIESTER (1971) descreve em Calliphora erythrocephala (Meigen, 1826) (Diptera, Calliphoridae), o desenvolvimento do epitélio imaginal e do "tecido reticulado". O que é descrito em $D$. hominis como tecido de aspecto conjuntivo denso 
corresponde ao "tecido reticulado" descrito pelos autores acima citados. Também foi observado, como ANDRIÉs $(1970,1972)$ que o "tecido reticulado" aparece previamente ao epitélio imaginal, mas não mais que um dia. Quem na verdade introduziu o termo "tecido reticulado" foi PÉREZ (1910) descrevendo a metamorfose de C. erythrocephala. Foi em seu trabalho que se encontrou a mesma interpretação que se deu a esse tecido em $D$. hominis, de que se assemelha a um tecido conjuntivo. Ele também admite que essas células do "tecido reticulado" são derivadas das ilhotas imaginais que nada mais são que as regenerativas.

DEEGENER $(1904,1908)$ apud PÉREZ (1910) observou que em alguns insetos ocorrem duas mudas epiteliais sucessivas, bem caracterizadas: a primeira, substituindo o epitélio larval e sendo funcional durante a fase pupal e em seguida, sendo substituído pelo epitélio imaginal definitivo. Em outros insetos como nas formigas PÉREZ (1910) relata que essa muda é mais abreviada sendo que as células imaginais substituem diretamente o epitélio larval, eliminando este último por quedas esporádicas de um grande número de células. O que se observou em $D$. hominis, foi semelhante ao descrito por PÉREZ (1910) em C. erythrocephala e por ANDRIÉs (1970) em Odonata (Aeshnidae): uma muda não tão abreviada como em formiga que não chega a apresentar uma camada pupal, e nem como em outros insetos que apresentam um epitélio pupal funcional. Foram observadas duas mudas epiteliais simultâneas. PÉREZ (1910) acredita que o epitélio pupal "nasce morto" e sua função é apenas isolar o epitélio larval, e com ele formar os "corpos amarelos", enquanto que ANDRIÉs (1970) acredita que além dessa função ele também pode colaborar na secreção que aparece de início separando-o do tecido imaginal definitivo. Pela quantidade de material polissacarídico que se detectou nessa camada em D. hominis, acredita-se que essa possibilidade seja válida.

ANDRIÉS (1972) descreve em nível de microscopia eletrônica a diferenciação das microvilosidades das células imaginais epiteliais do intestino médio de Odonata (Aeshnidae) e relata o aparecimento de uma secreção densa, de natureza polissacarídica, que cobre as células imaginais; afirma que elas são originárias de vesículas que brotam da própria célula, e que também podem ser secretadas pelas células do "tecido reticulado" tendo por função separar esses dois tecidos. Também foi observada essa secreção acidófila no espaço entre os dois tecidos pupais assim como demonstrou-se nos citoplasmas de ambos a presença de material polissacarídico. PÉREZ (1910) afirma que o líquido âmbar, espesso e mucilaginoso que preenche o lúmem do IM pupal, rodeando os corpos amarelos, são secreções próprias das novas células epiteliais, e as observações apresentadas aqui em $D$. hominis levam às mesmas conclusões.

Quanto ao processo de degeneração das células epiteliais larvais do intestino médio, tanto o presente trabalho, quanto os de PÉREZ (1910) e BAUTZ (1979) que estudaram C. erythrocephala (Diptera, Calliphoridae), como o de ANDRIÉs (1970) que estudou Odonata da família Aeshnidae mostram que as células, após serem expelidas para a luz do IM rodeadas pelo "tecido reticular", permanecem por algum tempo (no caso de D. hominis cerca de oito dias) ainda mantendo as características de células ativas. Elas são eliminadas topologicamente fora do organismo, na cavidade intestinal, onde os fagócitos não entram e onde também são protegidas pelo "tecido reticular" e pelo líquido que preenche a cavidade. Assim, considerando 
as características típicas de uma morte por apoptose (marginalização da cromatina, fragmentos celulares rodeados pela membrana plasmática e finalmente, a fagocitose desses fragmentos pelas células fagocitárias vizinhas), conclui-se que, as células do IM de $D$. hominis, apresentam uma morte celular programada, porém não do tipo apoptótico. As células musculares da parede sim, mostram típicas apoptoses.

PÉREZ (1910) descreve que na metade do período pupal de C. erythrocephala há variação no tamanho das células epiteliais do IM, as quais são mais altas nas extremidades e baixas na região central. Essa característica foi observada em pupa de nove dias. No final da pupação e nos adultos recém-emergidos, as células da porção torácica são nitidamente diferentes das abdominais. Não se observou no intestino médio de adultos de $D$. hominis células regenerativas. Essa situação é plausível uma vez que o adulto não se alimenta e vive no máximo 10 dias, durante os quais tem apenas o objetivo da reprodução.

\section{REFERÊNCIAS BIBLIOGRÁFICAS}

ANDRIÉs, J.C. 1970. Étude de l'activité des nids de regénération au cours de la métamorphose de l'intestin moyen d'Aeshna cyanea Mull. (Insecte: Odonate). Bull. Soc. Zool. 95: 85-97.

- 1972. Genèse des microvillosités de l'epithélium meséntérique de larve d'Aeshna cyanea. Jour. Microsc. 15: 181-204.

BAUTZ, A.M. 1979. Growth and degeneration of the larva abdominal epidermis in Calliphora erythrocephala (Meig) (Diptera: Calliphoridae) during larval life and metamorphosis. Int. Jour. Insect Morphol. Embryol. 4: 495-515.

DEPRIESTER, W. 1971. Ultrastructure of the midgut epithelial cells in the fly Calliphora erythrocephala. Jour. Ultrastruct. Res. 36: 783-805.

GregóRIO, E.A.; L.A. Toledo \& E. DE Lello. 1981. Ultraestrutura dos nefrócitos de Dermatobia hominis (Diptera, Cuterebridae). Naturalia 6: 21-32.

GREGóRIO, E.A.; V.N.D.P. SECCO; L.A. TOLEDO \& E. DE LELLO. 1990a. Ultrastructure of the ovary of the Dermatobia hominis (Diptera, Cuterebridae). I. Development during the $3^{\text {rd }}$ larval instar. Mem. Inst. Oswaldo Cruz. 85 (3): 305-313.

. 1990b. Ultrastructure of the ovary of the Dermatobia hominis (Diptera, Cuterebridae). II. Origin of the tunica propria in ovarioles. Mem. Inst. Oswaldo Cruz. 85 (3): 315-320.

- 1992. Ultrastructure of the ovary of the Dermatobia hominis (Diptera, Cuterebridae). III. Gonial cell degeneration. Mem. Inst. Oswaldo Cruz 87 (3): 375-380.

LELLo, E. DE; L.A. TOLEDO \& E.A. GREGóRIO. 1984. Diferenciação morfológica das gônadas em larvas de Dermatobia hominis (Diptera, Cuterebridae). Mem. Inst. Oswaldo Cruz. 79 (2): 211-219.

- 1987. Elementos figurados da hemolinfa da Dermatobia hominis (Diptera, Cuterebridae). Caracterização a nível de microscopia óptica, em larvas dos $2^{\circ}$ e $3^{\circ}$ ínstares. Mem. Inst. Oswaldo Cruz 82 (3): 351-358.

Lello, E. DE; E.A. GregórIo \& L.A. Toledo. 1985. Desenvolvimento das gônadas de Dermatobia hominis (Diptera, Cuterebridae). Mem. Inst. Oswaldo Cruz 80 (2): 159-170.

PÉrEZ, C. 1910. Recherches histologiques sur la métamorphose des mucides (Calliphora erythrocephala). Arch. Zool. 5: 1-274.

SNODGRass, R.E. 1935. Principles of Insect Morphology. New York, McGraw-Hill Book Co., $\mathrm{XIII}+667 \mathrm{p}$.

VieIRA, A.M. \& E. DE LeLLo. 1996. Post-embryonic development of the digestive tube of Dermatobia hominis Linnaeus Jr., 1781 (Diptera, Cuterebridae). Revta bras. Zool. 13 (4): 1063-1074.

VieIRA, A.M. \& E. DE LelLo. 2001. Desenvolvimento pós-embrionário do intestino anterior de Dermatobia hominis (Linnaeus Jr.) (Diptera, Cuterebridae). Revta bras. Zool. 18 (1): 81-90.

Recebido em 27.XII.1999; aceito em 29.III.2001. 